\author{
Дмитро Башманівський, \\ аспірант кафедри філософії та політології \\ Житомирського державного університету імені Івана Франка \\ ORCID: 0000-0001-6404-0544 \\ dmytrobash48@gmail.com
}

\title{
ПОНЯТТЯ ІНФОРМАЦІЙНОГО ПРОСТОРУ В КОНТЕКСТІ СОЦІАЛЬНО- ФІЛОСОФСЬКОГО ДОСЛІДЖЕННЯ
}

Розглянуто основні поняття інформаційного простору в контексті соиіальнофілософського дослідження. Здійснено теоретичний аналіз понять "інформація" та "простір" як об'єктів дослідження. Доведено актуальність вивчення інформаційного простору як одного з основних засобів створення та закріплення сочіальних змін у нинішньому глобалізованому світі. Зроблено висновок, щуо інформаційний простір є основою політичного, сочіально-економічного й культурного розвитку крайни. Формування єдиного інформаційного простору в різних сферах життєдіяльності є одним із найперспективніших напрямків розвитку сучасного інформаційного суспільства.

Ключові слова: простір, інформаџія, інформаційний простір, інформаційнокомунікативні технології, реклама, українсько-польські відносини.

\section{Baszmaniwsky Dmytro. Pojęcie przestrzeni informacyjnej w kontekście badań spoleczno- filozoficznych.}

W artykule rozważane sa podstawowe koncepcje przestrzeni informacyjnej w kontekście badań społeczno-filozoficznych. Została przeprowadzona teoretyczna analiza pojęć, , informacja” $i$ „przestrzeń” jako obiektów badań. Udowodniono znaczenie badania przestrzeni informacyjnej jako jednego z głównych sposobów tworzenia i utrwalania zmian społecznych $w$ dzisiejszym zglobalizowanym świecie. Stwierdzono, że przestrzeń informacyjna jest podstawa rozwoju politycznego, społeczno-gospodarczego i kulturalnego w kraju. Tworzenie jednej przestrzeni informacyjnej $w$ różnych sferach życia jest jednym z najbardziej obiecujących kierunków rozwoju wspólczesnego społeczeństwa informacyjnego.

Słowa kluczowe: przestrzeń, informacja, przestrzeń informacyjna, technologie informacyjne $i$ komunikacyjne, reklama, stosunki ukraińsko-polskie.

\section{Bashmanivskyi Dmytro. The concept of the information space in the context of socio- philosophical research}

The article deals with the concept of the information space in the context of socio-philosophical research. It carries out the theoretical analysis of the concepts of "information" and "space" as the objects of research, indicates the possibility of impact on the development and formation of a social thought. It also defines the topicality of studying the information space as one of the major means to create and consolidate social changes in the current globalized society; and substantiates the importance of social and philosophical research of the information space as a way of formating of modern person world perception and world view. In the article we have analyzed the works of researchers on this subject from antiquity to the present and emphasized that the formation of a single information space in different spheres of life is one of the most promising directions of development of the modern information based society. The information space is the basis of the political, socio-economic and cultural development of a country. It has to provide building of the information based society and entering into the world information space. That is why the information space is so interesting for social and philosophical research and needs further exploration. 
During researching we have concluded that the information space is one of the forms of comprehension of the modern world that is capable of influencing the public perception of the environment. Some processes related to information, its creation, collection, accumulation, etc, are carried out in it. The actions that take place in the modern information space can directly influence on the formation of personal orientations, that is why it is extremely important factor in forming and creating public opinion.

Key words: space, information, information space, information and communication technologies, advertising, Ukrainian and Polish relations.

Постановка проблеми в загальному вигляді та її зв'язок із важливими науковими й практичними завданнями. Інформація сьогодні стає цариною людської життєвої діяльності та активності, що становить основу інформаційно-комунікативної парадигми сучасного суспільства. Людство завжди цікавив інформаційний простір. Тому закономірно, що інформаційно-комунікативні технології посідають важливе місце не лише в сучасній журналістській діяльності, а й у суспільному житті загалом. Поява інформаційних технологій останнім часом почала формувати специфічний тип соціуму - інформаційнокомунікативний. Значною мірою до цього спонукали й глобалізаційні процеси сучасного світу. Інформаційний простір є одним з основних факторів впливу на суспільство, що має змогу формувати не лише поняття бажаного та соціально значущого, а спрямовує громадську думку, створює нові канони та світогляди. Під впливом нинішнього часу інформаційний простір видозмінюється, набуває нових рис, наприклад, поява друкарства, пізніше радіо та телебачення суттєво розширили сучасний інформаційний простір. Відтак, піддаючись інформаційно-комунікативному впливу технологій, які відкривають нові галузі виробництва, нові напрямки наукового дослідження 3 їх практичною складовою, у суспільстві відбуваються значні перетворення не лише духовного, а й матеріального життя.

Доказ цієї думки знаходимо в праці доктора філософських наук, професора В. Воронкової, зокрема, дослідниця зазначає, що "для забезпечення економічної конкурентоспроможності й політичної стабільності держави та розвитку мережного суспільства варто дотримуватися концепції інформатизації України, оскільки сучасний розвиток i впровадження інформаційних технологій на рівні держави відкриває широкі горизонти для країн, що розвиваються. Окрім того, відсутність уваги до змін, що відбуваються, обов'язково призведе до більшого відставання країни щодо традиційних показників - економіки, військової сили, політики, культурної самобутності. Тобто дослідження феномена глобальної інформатизації та ii можливих позитивних і негативних наслідків сьогодні необхідно здійснювати для забезпечення гідного місця України у світовій політиці" [5, с. 25].

Окремої уваги заслуговує дослідження означеної проблеми в умовах "гібридної війни", маніпулятивних впливів російської пропаганди. У контексті українсько-польських відносин інформаційний простір обох країн страждає від дезінформації з боку Російської Федерації. Узяти для прикладу хоча б дослідження польського блогера Марчіна Рея. Починаючи 32014 року, він вів розслідування-блог "Російська п’ята колона в Польщі", вивчаючи вплив Росії на інформаційний простір Польщі та ії політику. Дослідник показує, наскільки збільшилася кількість російської пропаганди з початком Революції гідності в Україні. 3 цього приводу Марчін Рей зазначає таке: "Зі стартом Майдану та війни на сході України в Польщі відбувся сплеск дезінформації та пропаганди від Російської Федерації. Так, між нами є історичні непорозуміння. Так, відбувалися жахливі речі й між Україною та Польщею. Я не перейду зараз до обговорення того, хто має рацію. Але існує цей факт - ми не погоджуємося щодо деяких речей у спільній історії. Наприклад, щодо Другої світової війни, Волинської трагедії, як іiі називають в Україні та Волинської різанини, як її називають у Польщі. Але це не повинно перешкоджати нам працювати разом проти спільного ворога. А це якраз те, чого росіяни не хочуть. Вони хочуть, аби ми пам'ятали про те, що нас розрізняє й забували про те, що нас єдна" [9]. Такі дані, своєю чергою, змушують нас ще більш активно цікавитися цим 
Дмитро Башманівський. Поняття інформаційного простору в контексті соиіально-філософського дослідження

поняттям не лише в межах українського потоку інформації, а i його русі в зарубіжних країнах. Саме тому поняття інформаційного простору потребує переосмислення та соціально-філософського дослідження.

Аналіз останніх досліджень і публікацій із зазначеної проблеми. Підтвердження актуальності дослідження знаходимо в зацікавленості зазначеною проблемою не лише вчених минулих століть, серед яких можна виокремити як філософів античності, наприклад, Сократа, Демокріта, Аристотеля, так і наступних поколінь - I. Ньютона, I. Канта, Г. Гегеля та інших. Зацікавленість зазначеною тематикою ми спостерігаємо в працях сучасних дослідників: 3. Беднарека, В. Воронкової, С. Довгого, М. Кісільовської, В. Литвина, О. Ліщинської, Є. Макаренка, С. Переслегіна, О. Сосніна та інших.

Концептуальна база філософії минулих століть, численні філософські теорії, які з нею пов'язані, спрямовували свої зусилля на дослідження цього питання. Проте лише в студіях XX століття спостерігаємо бачення та усвідомлення простору як багатовимірної інформації. Так, польська дослідниця Малгожата Кісільовська, розглядаючи це поняття, зазначає, що концепція інформаційного простору в науковій літературі була розроблена лише наприкінці дев'яностих років минулого століття [12, с. 37]. Саме інформацію ми розглядаємо як означальний критерій у людському бутті. Незважаючи на це, сучасні наукові дослідження інтерпретують поняття інформаційного простору досить схематично, розглядаючи його як особливу ланку фізичного простору та складову культурного буття.

Такий підхід викликаний філософсько-культурною та інформаційно-технологічною революцією останніх років. У сучасних дослідженнях існують суб'єкти, спільноти людей, які $\epsilon$ унікальними, тобто вони не мають подібних у минулих просторах. Серед них можна виділити мережеві організації, віртуальні співтовариства. Відтак логічно буде припустити, що завдяки цьому сучасний інформаційний простір в означенні своєї віртуальності активно взаємодіє та переплітається як із сучасним соціально-філософським простором, так i медіапростором. Польський дослідник Збігнев Беднарек у праці "Інформаційний простір для друкованих текстів в епоху масової культури", досліджуючи інформаційний простір 3МI, обгрунтовує думку, що в пресі останній реалізований щонайменше в трьох вимірах: "Фізичному (матеріальному) - кількість сторінок у газеті, розмір тексту; образному - образи, створені у свідомості читача, їхні способи поєднуватися між собою та переміщувати одержувача між ними; мережевому (віртуальному) - інтернет-газети" [11, с. 416].

На жаль, традиційне вивчення інформаційного простору як такого, навіть за найглибшого дослідження та розуміння цієї тематики, залишається обмеженим у більшості вчень та інформаційно-культурних теорій. Як наслідок, постала необхідність здійснення соціальнофілософського аналізу цього феномену, викликана тими динамічними поштовхами до розвитку технологій інформації, які вже декілька десятиліть активно проникають у життя людини та інтенсивно змінюють її характер та й саме буття.

Метою статті $\epsilon$ з'ясування поняття інформаційного простору в контексті соціальнофілософського дослідження, визначення основних витоків його оформлення, можливості впливу на формування свідомості людини.

Виклад основного матеріалу. У контексті соціально-філософського дослідження поняття інформаційного простору фігурують два терміни "інформація" та "простір". Останній на сьогодні $\epsilon$ визначальною складовою 3 погляду інших понять, зокрема, доволі часто фігурують такі поняття як "освітній" або "культурний" простір. Відтак уважаємо доцільним коротко охарактеризувати вищезазначене поняття. Передусім потрібно проаналізувати цей базовий термін у вузькому сенсі, а саме в сенсі характеристик тих теорій, які мають вплив на його сучасну суть. Тут можемо виділити дві теорії, які беруть свій початок ще в стародавній Греції. За одним із визначень, простором $\epsilon$ нескінченна місткість речей, територія рухомих тіл. Така теорія бере свій початок в атомістів. Так, один із засновників цієї філософської школи Демокріт, вважаючи ідею матерії як основну й беручи за основу нашого буття атом, намагався вирішити завдання елементних складових і зв'язків між ними. На думку філософа, 
буття всього існуючого пояснюється через рух атомів у просторі, тому природа в просторі, часі та космосі є нескінченною. За цією теорією, тіла утворюються з атомів, які можуть існувати та рухатися лише в порожньому просторі, який виступає для них своєрідним "вмістилищем" [1].

Протистоїть цій позиції інша концепція - Аристотеля. За нею заперечується вищезазначена теорія i, як наслідок, заперечується й простір як порожнє середовище. На думку філософа, усесвіт обмежується простором, але існує в нескінченності часу й формується 3 концентрованих кришталевих сфер, які рухаються з різною швидкістю, тобто простір розглядається не як "вмістилище", а як "місце". Сам Аристотель зазначав: "...порожнеча існувати не може, бо вона - це щось, що має величину, і одночасно ніщо, безтілесний початок: ні на що не діє і не зазнає дії; чого не може бути, тому що бути не може" [1]. Отже, ще раз отримуємо підтвердження про те, що простором, за філософом, $\epsilon$ сукупність місць, займаних різними тілами.

У середньовіччі простір уявлявся з позиції створення Богом світу i, як наслідок, у процесі цього творіння виник сам простір, тобто простір розглядається 3 позиції релігійних i моральних образів. Більшої абстрактності поняття простору набуває в епоху Відродження, зокрема, його розуміють як однорідне середовище, де відсутні будь-які тіла. Пізніше, разом із науковою революцією, простір стає матеріальним, входячи так у механічний світ. Наприклад, І. Ньютон трактує простір як самостійну сутність, яка може діяти як поряд із матерією, так і поза нею. Тобто взаємодія між простором, матерією та часом розглядається як взаємозв'язок незалежних субстанцій. Відтак властивості простору та часу є незалежними від будь-якого матеріального процесу, його характеру. Окрім незалежності, учений виділяє також абсолютність та універсальність цих процесів. Учений доходить висновку, що простір, матерія та час групуються одне 3 одним, проте не взаємодіють, перебуваючи у протиставленні. Аналізуючи зазначену концепцію, І. Ньютон спробував побудувати фізичну модель світу, визначивши простір як абсолютний, що існує незалежно від інших фізичних тіл [10, с. 154]. Отже, побудувавши концепцію про простір як "вмістилище" світу, він створив підгрунтя просторового уявлення сучасного часу.

Сутність та поняття простору намагався у своїх дослідженнях обгрунтувати Г. Гегель. Учені схиляються до думки, що саме його трактування є найбільш змістовними. Видатний філософ спробував осягнути простір 3 позиції абстрактності. Він формує визначення простору як форми окремої ідеї, яка не має якісного визначення. Дослідник дійшов висновку, що простором можна вважати певну "точечність, яка, будучи неіснуючою, одночасно $є$ "цілковитою безперервністю" [4]. 3 цього стає зрозумілим, що простором і є окрема абстракція.

Як бачимо, питання простору ще за часів античності призводило до дебатів, формувалися окремі визначення та думки різними філософами та їх школами. 3 часом, хоч це поняття $\mathrm{i}$ набуває окремих рис, багато з яких розвинулися з античної епохи, дослідження простору не втрачає своєї актуальності. Окрім вищеназваних дослідників, вагомий внесок здійснили Г. Ляйбніц, який вивчав простір крізь призму відношення між тілом, відстанню та напрямком, I. Кант, який аналізував сутність зазначеної проблеми з емпіричного боку, крізь досвід. Учений стверджує, що простір - це апріорне поняття, а тому людина, на його думку, сприймає світ тільки крізь простір. Пізніше з виникненням теорії відносності це поняття розглядається невід'ємно від часу.

Сьогодні існує думка 3 узагальненням окремих досліджень простору. Його характеризують як загальне абстрактне поняття, яке містить в собі різні компоненти, передусім простір пов'язують зі світосприйняттям.

Важливим для нашого дослідження є другий термін - "інформація". Це поняття було введено відносно недавно. Так, стародавні філософи розмірковували про буття, знання та багато іншого, але вони не задумувалися про сам спосіб існування та передачу знань. Схожа доля спіткала це поняття й у наступні віки. Лише з середини XX століття зазначений термін 
стає загальнонауковим. Вважається, що першим його ввів Клод Шеннон у 1948 році. Учений розглядав цей термін як усі види повідомлення. Проте, попри такий відносно пізній час виникнення цього поняття, інформація сьогодні посідає вагоме місце в житті суспільства. Виникли засоби масової інформації, технології, які іiі поширюють та обробляють, існує й концепція інформаційного суспільства, основою якої і є отримання, обмін, сприйняття i споживання інформації.

Напевно, через відносну "молодість" та багатовимірність цього поняття в науковому світі досі тривають дискусії щодо його визначення. Академік В. Вернадський, котрий одним із перших розмірковував про інформаційний простір, розглядає інформацію як один із соціальних факторів, що здатний сформувати ноосферу ("розумний" простір). Таким фактором учений вважає розвиток засобів обміну інформацією, які б інтегрували людей в єдине ціле [3]. На думку дослідника, інформація $є$ одним із засобів формування глобалізованого світу.

Попри швидкий розвиток технологій, які зумовлюють новизну цього поняття, інформаційний простір не можна назвати новим феноменом, оскільки людство завжди існувало поряд з інформаційними технологіями, а отже, і в самому просторі. Зокрема, автори В. Литвин, С. Довгий, В. Андрущенко в праці "Науково-освітній потенціал нації: погляд у XXI століття", підтверджуючи поняття людини в інформаційному просторі, зазначають: "Розширенню інформаційного простору сприяли поява друкарства i пошти, винахід телеграфу і телефону, відкриття радіо і телебачення. Значний i вирішальний внесок у глобалізацію інформаційного простору внесло масове застосування в усіх сферах діяльності людини сучасних інформаційно-комунікаційних технологій, які істотно змінюють не тільки спосіб виробництва товарів і послуг, але й організацію і форми проведення дозвілля, реалізацію людиною своїх громадянських прав, методи і форми виховання та освіти. Вони впливають на соціальну структуру суспільства, економіку, політику, розвиток суспільних інститутів" [7, с. 338].

Як бачимо, людина завжди перебувала поряд 3 інформаційним простором, навіть, можливо, безпосередньо в ньому. Попри це, через характерну особливість цього поняття, а саме зміну сутності інформаційного простору з розвитком суспільства та часом, у якому воно існує, виникає потреба в його осмисленні з погляду сучасного світогляду. 3 цією метою зробимо спробу визначення самого поняття "інформаційний простір". Насамперед зауважимо, що точної дефініції цього поняття дати неможливо, оскільки його визначення залежить від інформаційних складових самого буття, а вони не є сталими й швидко змінюються, що спричиняє як культурну швидкозмінюваність, так і трансформацію наукової та філософської парадигми. Варто зазначити, що інформаційний простір активно досліджувався завдяки ідеалістичним теоріям філософів. Зокрема, у С. Переслегіна інформаційний простір визначається як "світ імен та назв, близький онтологічному" [8]. Більш грунтовне визначення зустрічаємо в I. Арістової: "Сдиний інформаційний простір - це сукупність баз і банків даних, технологій їх ведення та використання, інформаційнотелекомунікаційних систем і мереж, що функціонують на основі єдиних принципів і за загальними правилами, що забезпечує інформаційну взаємодію організацій і громадян, а також задоволення їх інформаційних потреб" [2, с. 143].

Ще більшого сенсу цьому поняттю надає Є. Макаренко, зокрема в дослідженні "Свропейська інформаційна політика", де розглядається єдиний інформаційний простір країни. У вченого фігурують такі терміни, як "інформаційні ресурси" та "інформаційна інфраструктура". Дослідник наголошує, що сукупність цих понять дає змогу створити умови для безпечної взаємодії держави з їі громадянами та організаціями і, як наслідок, їх рівності в можливостях доступу до відкритих інформаційних ресурсів. Така співпраця, поширюючись територією держави, має змогу задовольнити їх інформаційні потреби, зберігаючи при цьому баланс інтересів щодо входження до світового інформаційного простору та забезпечуючи 
національний інформаційний суверенітет [6, с. 257].

У сучасних умовах інформаційної глобалізації інформаційний простір формує громадську думку не тільки окремого соціуму, а й світосприйняття світової спільноти. Доказ цієї тези знаходимо у В. Воронкової, зокрема, у статті "Глобальна інформатизація як головна тенденція соціоприродної еволюції людства". У ній дослідниця чітко виокремлює фактори, що впливають на розвиток інформаційного простору цієї спільноти, серед яких розвиток глобальної системи телебачення та радіомовлення на основі використання супутникових і наземних систем зв'язку; розвиток глобальних інформаційно-телекомунікаційних мереж; глобалізація телефонного зв'язку, зокрема й мобільного; формування принципово нових засобів і технологій для інформаційних комунікацій; створення глобальної навігаційної супутникової системи; формування й розвиток інформаційних полісів, пов'язаних із формуванням глобального інформаційного простору через посередництво інформаційноінтелектуальних систем" [5, с. 15].

Аналізуючи вищезазначене, можна дійти висновку, що інформаційний простір є однією 3 форм осягнення сучасного світу, яка здатна впливати на суспільну картину сприйняття навколишньої дійсності. У ньому відбуваються процеси, пов'язані 3 інформацією, ії створенням, збиранням, накопиченням тощо. Дії, що відбуваються в сучасному інформаційному просторі, дають змогу безпосередньо впливати на особистісні орієнтації, а тому є надзвичайно важливим чинником формування громадської думки.

Висновки та перспективи подальшого дослідження проблеми. Вивчення інформаційно-комунікативної парадигми сучасного соціуму дозволяє масштабно й повно визначити зміст поняття інформації як сукупності ідей, принципів, установлень, форм інформаційно-комунікативного суспільства. Інформаційний простір є основою політичного, соціально-економічного й культурного розвитку країни. Формування єдиного інформаційного простору в різних сферах життєдіяльності $є$ одним із найперспективніших напрямків розвитку сучасного інформаційного суспільства. Він повинен забезпечити побудову інформаційного суспільства й входження у світовий інформаційний простір. Саме тому поняття інформаційного простору є настільки цікавим для соціально-філософського дослідження й потребує подальших розвідок.

\section{Список використаних джерел та літератури}

1. Аристотель. Категории В Этика. Политика. Риторика. Поэтика. Категории. Мн., 1998. С. 11131166.

2. Арістова I. В. Державна інформаційна політика: організаційно-правові аспекти: монографія / За заг. ред. проф. Бандурки О. М. Харків, 2000. 368 с.

3. Вернадский В. И. Несколько слов о ноосфере [Электронный ресурс]. Режим доступа: http://lib.ru/FILOSOF/WERNADSKIJ/noos.txt. (дата звернення: 15.08.2019).

4. Гегель Г. В. Ф. Философия природы: URL:http://ru.philosophy.kiev.ua/library/katr/hegel_phil natura1.html. (дата звернення: 15.08.2019)

5. Воронкова В. Г. Глобальна інформатизація як головна тенденція соціоприродної еволюції людства. Гуманітарний вісник ЗДІА. 2012. № 51. С. 14-26.

6. Макаренко С. А. Свропейська інформаційна політика. К.: Наша культура і наука, 2000. 368 с.

7. Науково-освітній потенціал нації: погляд у XXI століття: [у 3 кн.] / авт. кол.: В. Литвин, С. Довгий, В. Андрущенко та ін. К., 2004. Кн. 1.638 с.

8. Переслегин С. Того, что достаточно для Геродота, мало для Герострата... URL:http://www.igstab.ru/materials/Pereslegin/Per_Gerodot.htm (дата звернення: 15.08.2019).

9. Польща потерпає від російської пропаганди після початку війни в Україні - Марчін Рей. URL:https://hromadske.radio/podcasts/dno/rosiyska-p-yata-kolona-polshchi-govorymo-z-blogeromrozsliduvachem

10. Пушкарьова М. В. Основна концепція теорії часу і простору Ісаака Ньютона. Збірник наукових прачь Кам'янець-Подільського національного університету ім. Івана Огієнка. 2016. Вип. 22. С. 152 156.

11. Przestrzeń informacyjna tekstów prasowych w dobie kultury masowej Acta Universitatis Lodziensis. Folia Litteraria Polonica. 2010. Tom 13. Zbigniew Bednarek: s. 415-422. 
12. Kisilowska M. Przestrzen informacyjna jako termin informatologiczny. Zagadnienia Informacji Naukowej. 2011. № 2. S. 35-52.

\section{References (translated \& transliterated)}

1. Aristotel (1998). Kategorii [Categories] in Etika. Politika. Ritorika. Poetika. Kategorii. Mn. 1113-1166. [in Russian].

2. Aristova, I. V. (2000). Derzhavna informatsiina polityka: orhanizatsiino-pravovi aspekty: monohrafiia; [State information policy: organizational and legal aspects] / Za zah. red. prof. Bandurky O. M. Kharkiv. 368. [in Ukrainian].

3. Vernadskii, V. I. Neskolko slov o noosfere [A few words about the noosphere] Rezhim dostupa: http://lib.ru/FILOSOF/WERNADSKIJ/noos.txt. [in Russian].

4. Gegel Georg V. F. Filosofiia prirody [The philosophy of nature] [Elektronnyiy resurs]. Rezhim dostupa: http://ru.philosophy.kiev.ua/library/katr/hegel phil natura1.html.

5. Voronkova, V. H. (2012) Hlobalna informatyzatsiia yak holovna tendentsiia sotsiopryrodnoi evoliutsii liudstva [Global informatization as the main tendency of socio-natural evolution of humanity] Humanitarnyi visnyk ZDIA. 51. 14-26. [in Ukrainian].

6. Makarenko, Ye. A. (2000) Yevropeiska informatsiina polityka [European Information Policy]. K.: Nasha kultura i nauka. [in Ukrainian].

7. Naukovo-osvitnii potentsial natsiii: pohliad u XXI stolittia (2004) [The scientific and educational potential of the nation: a perspective in the 21 st century]: [u 3 kn.] / avt. kol.: V. Litvin, S. Dovgiy, V. Andruschenko ta in. K. Kn. 1. [in Ukrainian].

8. Pereslegin, S. Togo, chto dostatochno dlia Gerodota, malo dlia Gerostrata... [What is enough for Herodotus is not enough for Herostratus]: http://www.igstab.ru/materials/Pereslegin/Per_Gerodot.htm [in Russian]

9. Polshcha poterpaie vid rosiiskoi propahandy pislia pochatku viiny v Ukraini - Marchin Rei [Poland is suffering from Russian propaganda after the outbreak of the war in Ukraine - Marcin Ray]: https://hromadske.radio/podcasts/dno/rosiyska-p-yata-kolona-polshchi-govorymo-z-blogeromrozsliduvachem [in Ukrainian].

10. Pushkarova, M. V. (2016). Osnovna kontseptsiia teorii chasu i prostoru Isaaka Niutona [The basic concept of the theory of time and space by Isaac Newton] // Zbirnyk naukovykh prats Kamianets-Podilskoho natsionalnoho universytetu im. Ivana Ohiienka. Vyp. 22. 152-156. [in Ukrainian].

11. Przestrzeń informacyjna tekstów prasowych w dobie kultury masowej (2010). [Information space for press texts in the era of mass culture] Acta Universitatis Lodziensis. Folia Litteraria Polonica. Tom 13 Zbigniew Bednarek. 415-422. [in Polish].

12. Kisilowska, M. (2011) Przestrzen informacyjna jako termin informatologiczny [The information space as an information science term]. Zagadnienia Informacji Naukowej. 2. 35-52. [in Polish]. 